\title{
ANALISIS ISI LAMBUNG IKAN CAKALANG (Katsuwonus pelamis) DAN IKAN MADIDIHANG (Thunnus albacares) YANG DIDARATKAN DI BITUNG, SULAWESI UTARA
}

\author{
Siti Mardlijah'1) \\ 1) Peneliti pada Balai Riset Perikanan Laut, Muara Baru-Jakarta \\ Teregristrasi I tanggal: 13 Agustus 2007; Diterima setelah perbaikan tanggal: 4 Pebruari 2008; \\ Disetujui terbit tanggal: 15 April 2008
}

\begin{abstract}
ABSTRAK
Penelitian ini telah dilakukan terhadap isi lambung ikan cakalang (Katsuwonus pelamis) hasil tangkapan pole and line dan ikan madidihang (Thunnus albacares) hasil tangkapan hand line yang didaratkan di Bitung, Sulawesi Utara pada bulan Mei, Juli, dan September 2005. Penelitian ini bertujuan untuk mengetahui komposisi jenis makanan ikan cakalang (Katsuwonus pelamis) dan ikan madidihang (Thunnus albacares). Contoh ikan cakalang (Katsuwonus pelamis) berjumlah 69 ekor dan contoh ikan madidihang (Thunnus albacares) berjumlah 63 ekor. Pengambilan contoh dilakukan di perusahaan perikanan dan tempat pengasapan atau fufu cakalang. Pengamatan dilakukan secara visual dan gravimetrik kemudian dianalisis dengan metode indeks of preponderance. Hasil penelitian menunjukkan bahwa komposisi makanan ke-2 jenis ikan pelagis besar tersebut berubah-ubah dan memiliki kemiripan terhadap 1 jenis makanan yaitu ikan malalugis (Decapterus macarellus), yang merupakan makanan utama ikan cakalang (Katsuwonus pelamis) dan ikan madidihang (Thunnus albacares).
\end{abstract}

KATAKUNCl: cakalang, madidihang, isi lambung, Bitung

ABSTRACT: Stomach content analysis of skipjack tuna and yellow fin tuna landed in Bitung, North Sulawesi. By: Siti Mardlijah

Stomach content analysis of skipjack tuna (Katsuwonus pelamis) which was caught by pole and line and yellow fin tuna (Thunnus albacares) caught by hand line, landed in Bitung, North Sulawesi in May, July, and September 2005 were conducted. The objective of the experiment is to know dietary composition of skipjack tuna (Katsuwonus pelamis) and yellow fin tuna (Thunnus albacares). The number of specimen observed 69 of skipjack tunas (Katsuwonus pelamis) and 63 of yellow fin tunas (Thunnus albacares). Sampling site were located in fishery company and at a small scale fish smoked industry. Stomach content analysis of the two fishes were observed visually measured and gravimetrically. The stomach content analysis was analysed based on indeks of preponderance) method. Result shows, the stomach content of skipjack tuna (Katsuwonus pelamis) and yellow fin tuna (Thunnus albacares) related changes and similar among one species are scad mackerel fishes (Decapterus macarellus). Therefore, scad mackerel fishes (Decapterus macarellus) is the dominant food for both skipjack tuna (Katsuwonus pelamis) and yellow fin tuna (Thunnus albacares).

\section{KEYWORDS: $\quad$ skipjack tuna, yellow fin tuna, stomach content, Bitung}

\section{PENDAHULUAN}

Makanan adalah segala sesuatu yang dapat dimakan dan diserap oleh ikan sehingga dapat digunakan untuk menjalankan metabolisme tubuh. Menurut Effendie (2002), makanan adalah bahan, zat, atau organisme yang dapat dimanfaatkan ikan untuk menunjang kebutuhan hidup. Informasi tentang makan dan kebiasaan makan ikan sangat penting untuk memahami sejarah hidup, termasuk pertumbuhan, migrasi, dan untuk pengelolaan perikanan secara komersial. Pengetahuan tentang perairan sumber makanan dari stok ikan komersial memberi pengalaman berharga bagi nelayan dalam menentukan daerah penangkapan secara lebih menguntungkan.

Secara umum, ikan mengawali hidup dengan memanfaatkan makanan sesuai dengan ukuran bukaan mulut. Setelah bertambah dewasa, makanan akan berubah baik kualitas maupun kuantitas (Effendie, 2002). Banyak jenis ikan dapat menyesuaikan diri dengan persediaan makanan dalam perairan sehubungan dengan musim yang berlaku. Ikan dengan jenis dan ukuran yang sama, hidup dalam suatu perairan yang berbeda, dapat berbeda kebiasaan makanan. Demikian pula dalam suatu perairan, jika terjadi perubahan lingkungan akan 
menyebabkan perubahan ketersediaan makanan, sehingga ikan akan mengubah kebiasaan makanan (Effendie 1979).

Makanan merupakan faktor yang menentukan bagi populasi, pertumbuhan, dan kondisi ikan (Effendie, 1979). Di perairan, kebutuhan ikan sudah tersedia yaitu berupa makanan alami, baik berupa hewan (zooplankton, invertebrata, dan vertebrata), tumbuhan (fitoplankton dan tumbuhan air), dan organisme mati (detritus). Selain itu, organisme yang dapat menjadi makanan ikan tersebut tergantung pada tropic level (Sjafei et al., 1989).

Kebiasaan makanan, menurut Gunarso (1985) adalah makanan yang dimakan ikan mencakup jenis dan jumlah makanan. Kebiasaan makanan ikan dipengaruhi oleh beberapa faktor antara lain habitat hidup, kesukaan terhadap jenis makanan tertentu, musim, ukuran, dan umur ikan (Lagler, 1956). Sedangkan menurut Effendie (2002), faktor-faktor yang menentukan suatu spesies ikan akan memakan jenis organisme makanan adalah ketersediaan makanan, ukuran makanan, warna, rasa, tekstur, dan selera ikan terhadap makanan.

Prinsip yang dikembangkan untuk mengetahui jenis makanan adalah dengan mengidentifikasi dari pencernaan (makanan yang telah dimakan oleh ikan). Nikolsky (1963) mengklasifikasikan makanan menjadi 4 kategori yaitu makanan utama adalah makanan yang dimakan dalam jumlah besar, makanan pelengkap adalah makanan yang dimakan dalam jumlah sedikit, makanan tambahan adalah makanan yang dimakan dalam jumlah sangat sedikit, dan makanan pengganti yang hanya dikonsumsi jika makanan utama tidak tersedia.

Tulisan ini akan menyajikan hasil analisis isi lambung ikan cakalang (Katsuwonus pelamis) dan ikan madidihang (Thunnus albacares) yang didaratkan di Bitung pada tahun 2005. Identifikasi jenis-jenis makanan sangat penting untuk memahami biologi ikan tersebut.

Studi makanan dapat memperlihatkan secara mendetail hubungan ekologis di antara organisme, sehingga diperlukan identifikasi secara menyeluruh dari jenis-jenis makanan tersebut. Organisme hidup berinteraksi satu dengan yang lain dan dengan lingkungan abiotik, tidak ada organisme hidup bebas dari lingkungan. Komposisi dari makanan ikan akan membantu menjelaskan kemungkinan habitat yang dikunjungi (Lagler, 1956; Kagwade, 1967; Holden \& Raitt, 1974).
Jumlah sediaan ikan di suatu lokasi merupakan fungsi dari potensialitas makanan, sehingga pengetahuan yang benar dari hubungan antar ikan dengan organisme makanan sangat penting untuk prediksi dan eksploitasi dari sediaan ikan tersebut (Rao, 1974; Nikolsky, 1963).

\section{BAHAN DAN METODE}

\section{Bahan, Waktu, dan Lokasi Pengambilan Contoh}

Ikan cakalang (Katsuwonus pelamis), hasil tangkapan dari pole and line berjumlah 69 ekor (kisaran FL 49 sampai dengan $63 \mathrm{~cm}$ ) dan ikan madidihang (Thunnus albacares), hasil tangkapan dari hand line berjumlah 63 ekor (kisaran FL 75 sampai dengan 155 $\mathrm{cm}$ ) telah diamati isi lambung. Pengamatan dilakukan pada bulan Mei, Juli, dan September 2005. Pengambilan contoh dilakukan di Bitung, Sulawesi Utara yaitu pada perusahaan perikanan (P.T. Deho Canning) dan tempat pengasapan atau fufu cakalang. Contoh ikan ditangkap di perairan Laut Sulawesi.

\section{Metode Pengamatan}

1. Lambung ditimbang kemudian dibuka dan diambil isi lambung.

2. Isi lambung diidentifikasi dan dikelompokkan menurut jenis.

3. Untuk ikan yang sudah hancur (tidak teridentifikasi) dikelompokkan dalam ikan hancur, begitu juga untuk udang dan jenis yang lain.

4. Tiap-tiap jenis isi lambung ditimbang.

5. Pengamatan dilakukan secara visual dan langsung di lapangan.

6. Untuk jenis ikan yang utuh diidentifikasi dengan mengacu pada Tarp \& Kailola (1984) dan untuk jenis Cephalopoda dan Krustasean mengacu pada Carpenter \& Niem (1998).

\section{Analisis Data}

Dalam menganalisis makanan utama suatu organisme, data dianalisis dengan metode index of preponderance yang dikembangkan oleh Natarjan \& Jingran (1962) dengan rumus:

$$
I P=\frac{(v i \times o i)}{\sum(v i \times o i)} \times 100 \%
$$

di mana:

$\mathrm{IP}=$ index of preponderance untuk satu jenis makanan tertentu

$\mathrm{Vi}=$ persentase bobot satu jenis makanan 
$\mathrm{O} i=\underset{\text { persentase kehadiran }}{\text { makanan }}$
mK) suatu jenis

Nilai oi atau FK diperoleh dengan rumus:

$$
F K=\frac{A}{B} \times 100 \%
$$

di mana:

$\mathrm{Fk}=$ persentase kehadiran suatu jenis makanan (oi)

$\mathrm{A}=$ tingkat kehadiran jenis makanan ke-1 dalam organisme

$B=$ total organisme yang lambung berisi makanan

Dalam perhitungan dilakukan modifikasi rumus index of preponderance, dengan mengganti Vi atau persentase penutupan jenis makanan tertentu dengan persentase bobot, sehingga hasil yang diharapkan lebih akurat.

Jika suatu jenis makanan mempunyai nilai IP $>40 \%$ berarti jenis makanan itu termasuk makanan utama, nilai index of preponderance 4 sampai dengan $40 \%$ berarti jenis makanan itu termasuk makanan pelengkap, dan jika nilai $\mathrm{IP}<4 \%$, maka jenis makanan tersebut merupakan makanan tambahan (Nikolsky, 1963).

\section{HASIL DAN BAHASAN}

\section{HASIL}

\section{Cakalang (Katsuwonus pelamis)}

Jenis ikan yang ditemukan dalam lambung dan ikan yang berasal dari alam atau umpan yang dilemparkan ke laut pada waktu operasi dapat dibedakan secara visual. Ikan yang berasal dari alam, tidak ada bekas pancing di bagian badan seperti pada bagian dorsal, ventral, atau bagian pangkal ekor. Sedangkan apabila ikan tersebut merupakan ikan umpan, terdapat bekas pancing di bagian badan.

Hasil analisis isi lambung ikan cakalang (Katsuwonus pelamis) dapat dilihat pada Gambar 1, dengan komposisi jenis makanan ikan cakalang (Katsuwonus pelamis) terdiri atas ikan malalugis (Decapterus macarellus), ikan sardin (Clupeidae), kepiting (Portunidae), ikan kembung (Rastrelligersp.), dan ikan hancur. Sebagai makanan utama adalah ikan malalugis (Decapterus macarellus) yang kehadiran mencapai $57 \%$, ikan sardin (Clupeidae) dengan kehadiran 9\%, dan ikan kembung (Rastrelliger sp.) $4 \%$ sebagai makanan pelengkap, sedangkan kepiting (Portunidae) sebagai makanan tambahan dengan kehadiran 0,09\%, ikan hancur yang dimaksud adalah ikan yang tidak teridentifikasi jenis dengan frekuensi kehadiran $30 \%$.

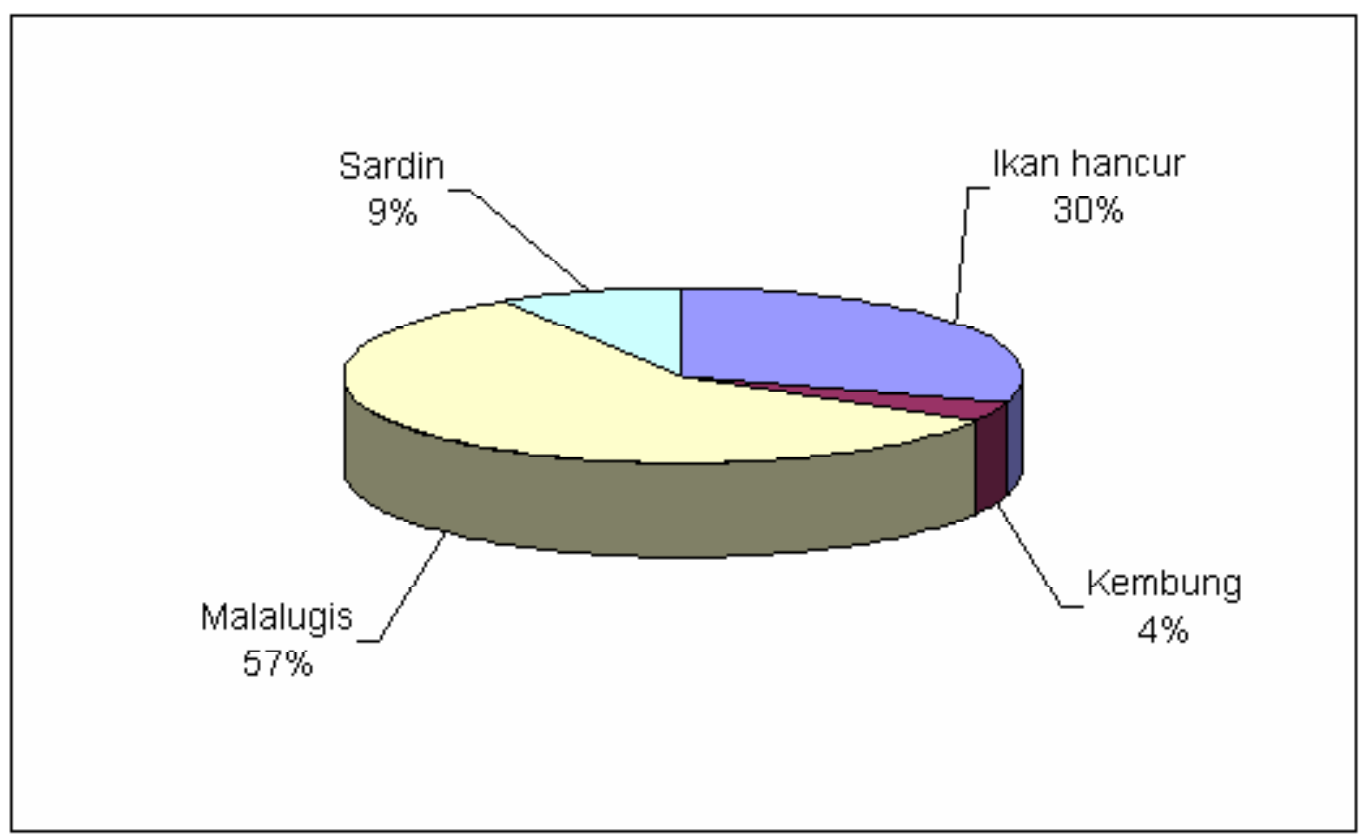

Gambar 1. Hasil analisis isi lambung ikan cakalang (Katsuwonus pelamis) yang didaratkan di Bitung. Figure 1. Stomach content analysis of skipjack tuna (Katsuwonus pelamis) landed in Bitung. 
Dragovich (1970) menemukan bahwa ada 3 jenis makanan yang utama dari ikan cakalang (Katsuwonus pelamis) yang tertangkap di Samudera Atlantik yaitu ikan, krustasean, dan moluska. Di Pasifik Barat, Alverson (1963) menemukan krustasean menjadi makanan utama, kemudian ikan dan cephalopoda. Kawasaki \& Asano (1962) menemukan ikan merupakan makanan utama ikan cakalang (Katsuwonus pelamis) yang tertangkap di Samudera Pasifik. Welsh, 1949; Yuen, 1959; Waldron \& King, 1963, mendapatkan bahwa ikan merupakan makanan penting ikan cakalang (Katsuwonus pelamis) yang tertangkap di perairan Hawai. Jelas terlihat bahwa makanan ikan cakalang (Katsuwonus pelamis) terdiri atas ikan, moluska, dan krustasean dengan proporsi yang bervariasi pada setiap lokasi. Yuen, 1959; Alverson, 1963; Nakamura, 1965, mengatakan bahwa ikan cakalang (Katsuwonus pelamis) yang berukuran lebih besar mempunyai ketergantungan yang cukup besar terhadap ikan daripada krustasean dan moluska.

Ukuran ikan-ikan yang ditemukan dalam lambung ikan cakalang (Katsuwonus pelamis) disajikan pada Gambar 2 sebagai berikut.

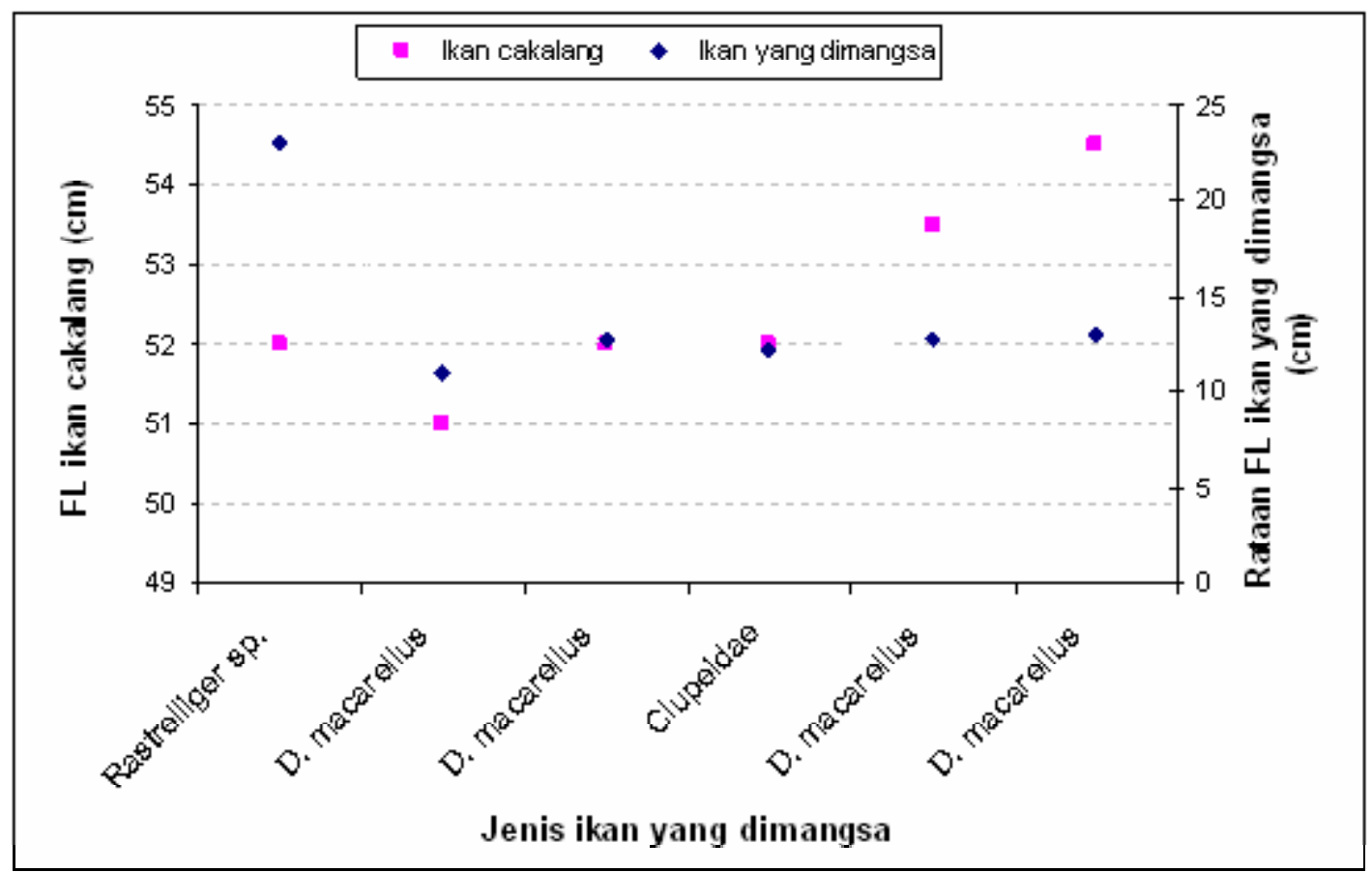

Gambar 2. Ukuran ikan yang ditemukan dalam lambung ikan cakalang (Katsuwonus pelamis) yang didaratkan di Bitung.

Figure 2. Fish size from stomach content of skipjack tuna (Katsuwonus pelamis) landed in Bitung.

Dari Gambar 2, tersebut terlihat bahwa ukuran ikanikan yang dimangsa tidak menggambarkan ukuran ikan pemangsa, dalam hal ini ikan cakalang (Katsuwonus pelamis). Misal ikan kembung (Rastrelliger sp.) dengan rata-rata FL $23 \mathrm{~cm}$ ditemukan dalam lambung ikan cakalang (Katsuwonus pelamis) dengan ukuran FL $52 \mathrm{~cm}$, sedangkan ikan malalugis (Decapterus macarellus) dengan ukuran lebih kecil (rata-rata FL $13 \mathrm{~cm}$ ) ditemukan dalam lambung ikan cakalang (Katsuwonus pelamis) yang berukuran lebih besar (FL $54,5 \mathrm{~cm})$. Hal tersebut, menunjukkan bahwa ukuran ikan yang dimangsa tidak menggambarkan ukuran ikan yang memangsa. Literatur yang mendukung pernyataan tersebut belum ditemukan. Di samping itu, dimungkinkan karena jumlah contoh yang terbatas sehingga kurang mewakili populasi di alam.

\section{Madidihang (Thunnus albacares)}

Hasil analisis isi lambung ikan madidihang (Thunnus albacares) menunjukkan bahwa komposisi makanan lebih bervariasi dibandingkan dengan ikan cakalang (Katsuwonus pelamis) (Gambar 3). Hasil pengamatan menunjukkan bahwa komposisi makanan ikan madidihang ( Thunnus albacares) didominasi oleh ikan malalugis (Decapterus macarellus) 54\% sebagai makanan utama, ikan suro atau sunglir (Elagatis bipinnulatus) $5 \%$ sebagai makanan pelengkap, sedangkan ikan buntal (Ostraciidae), ikan deho (Auxis thazard), dan udang (Penaeidae) sebagai makanan pengganti. 


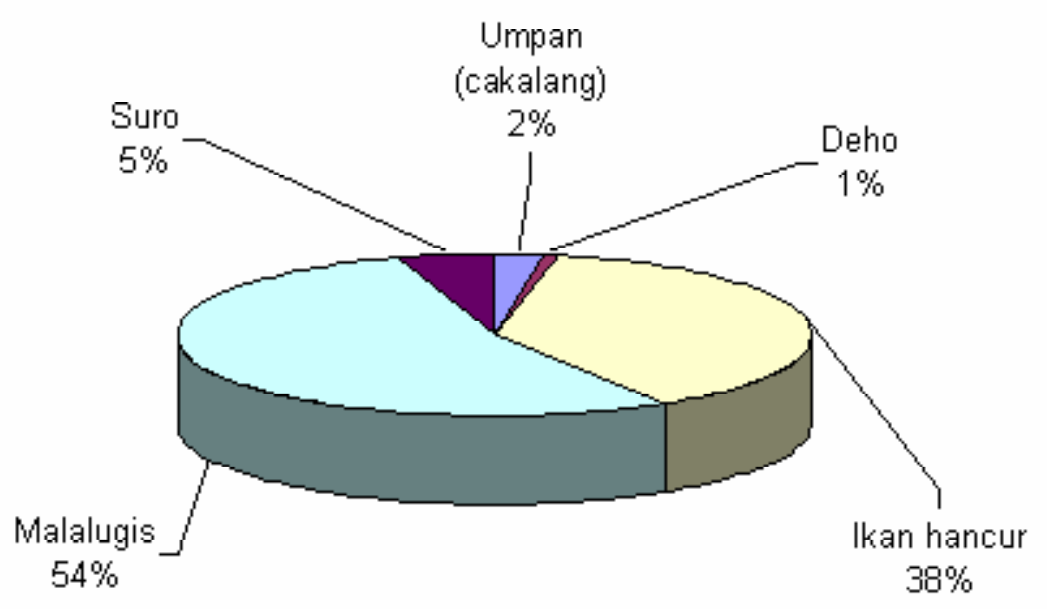

Gambar 3. Hasil analisis isi lambung ikan madidihang (Thunnus albacares) yang didaratkan di Bitung. Figure 3. Stomach content analysis of yellowfin tuna (Thunnus albacares) landed in Bitung.

Gambar 4.

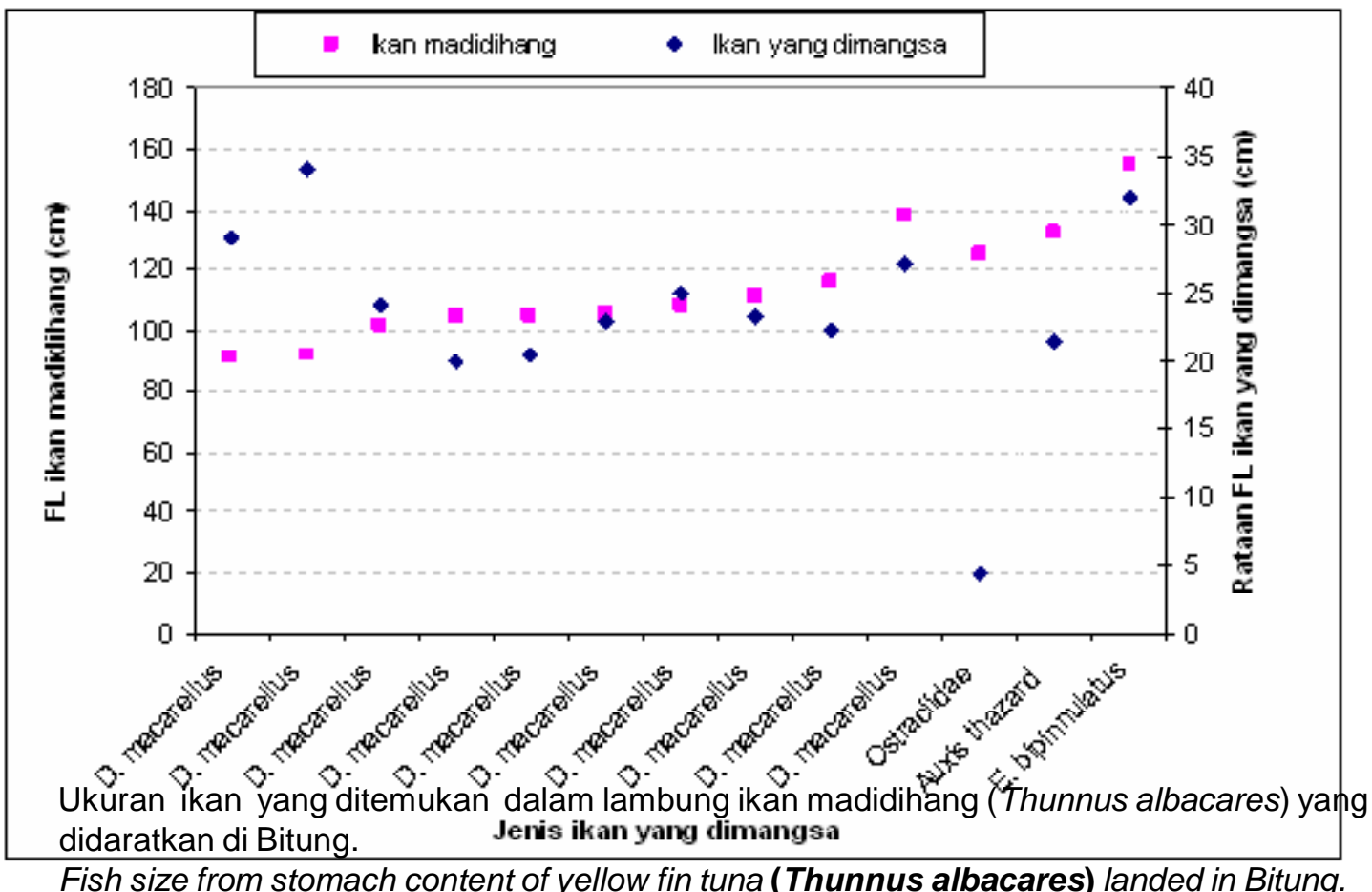

Figure 4. Fish size from stomach content of yellow fin tuna (Thunnus albacares) landed in Bitung.

McLean (2005), mengatakan bahwa analisis terhadap isi lambung ikan madidihang (Thunnus albacares) dari perairan Hawaii terdiri atas megalop, stomatopoda, ikan, dan cephalopoda.
Menard et al. (2000), melakukan analisis isi lambung ikan madidihang (Thunnus albacares) hasil tangkapan purse seine (pukat cincin) di perairan Teluk Guinea yang ditangkap di sekitar rumpon dan tidak 
di sekitar rumpon. Jenis makanan ikan madidihang (Thunnus albacares) berukuran kurang dari $90 \mathrm{~cm}$ yang ditangkap di sekitar rumpon terdiri atas Vinciguerria nimbaria (famili Photichthyidae, sejenis ikan mesopelagis dari mikronekton), cephalopoda, lain-lain, dan jenis tidak terdeterminasi (dominan). Sedangkan ikan madidihang (Thunnus albacares) berukuran lebih dari $90 \mathrm{~cm}$, jenis makanan didominasi oleh Scombridae 96\%. Ikan madidihang (Thunnus albacares) yang ditangkap tidak di sekitar rumpon, jenis makanan ikan berukuran kurang dari $90 \mathrm{~cm}$ terdiri atas Vinciguerria nimbaria (dominan), cephalopoda, lain-lain, dan jenis tidak terdeterminasi. Untuk ikan berukuran lebih dari $90 \mathrm{~cm}$, jenis makanan terdiri atas scombridae, cubiceps, dan lain-lain jenis tidak terdeterminasi (dominan).

Gardieff (2003), menemukan 37 famili dan 8 ordo invertebrata dalam lambung ikan madidihang (Thunnus albacares) dan jenis makanan yang lain meliputi lumba-lumba (Dolphin sp.), pilchard, anchovy (teri), ikan terbang (Hirundichtys oxycephalus), mackerel, lancetfish, cumi-cumi (Loligo sp.), gurita, udang, lobster, dan jenis kepiting.

Ukuran ikan-ikan yang ditemukan dalam lambung ikan madidihang (Thunnus albacares) disajikan pada Gambar 4 sebagai berikut.

Dari Gambar 4. tersebut dapat dilihat bahwa ikan malalugis (Decapterus macarellus) dengan rata-rata ukuran $34 \mathrm{~cm}$ ditemukan dalam lambung ikan madidihang (Thunnus albacares) yang berukuran lebih kecil $(92 \mathrm{~cm})$ dan sebaliknya, ikan malalugis (Thunnus albacares) dengan rata-rata ukuran $27 \mathrm{~cm}$ ditemukan dalam lambung ikan madidihang (Thunnus albacares) yang berukuran lebih besar $(138 \mathrm{~cm})$. Di samping itu, dapat dilihat pula bahwa ikan buntal yang berukuran $4,5 \mathrm{~cm}$ ditemukan dalam lambung ikan madidihang (Thunnus albacares) yang berukuran 125 $\mathrm{cm}$. Seperti halnya pada ikan cakalang (Katsuwonus pelamis), bahwa ukuran ikan yang dimangsa tidak menggambarkan ukuran ikan yang memangsa.

\section{BAHASAN}

Komposisi jenis makanan ikan cakalang (Katsuwonus pelamis), dan ikan madidihang (Thunnus albacares) berubah-ubah dan memiliki kesamaan terhadap 1 jenis makanan utama yaitu ikan malalugis (Decapterus macarellus) dengan ukuran yang berbeda. Ikan malalugis (Decapterus macarellus) yang ditemukan dalam lambung ikan cakalang (Katsuwonus pelamis) $57 \%$ dengan rata-rata ukuran FL 12,4 cm, sedangkan ikan malalugis (Decapterus macarellus) yang ditemukan dalam lambung ikan madidihang
(Thunnus albacares) 54\% dengan rata-rata ukuran FL 24,8 cm.

Ikan cakalang (Katsuwonus pelamis) merupakan hasil tangkapan pole and line dan ikan madidihang (Thunnus albacares) merupakan hasil tangkapan hand line yang beroperasi di Laut Sulawesi. Ke-2 armada tersebut beroperasi di rumpon di mana tempat ikan-ikan pelagis kecil berkumpul, termasuk ikan malalugis (Decapterus macarellus) yang merupakan jenis ikan pelagis kecil dominan di Laut Sulawesi. Dalam Statistik Perikanan Tangkap (2005) dikatakan bahwa rata-rata produksi ikan malalugis (Decapterus macarellus) di Laut Sulawesi dari tahun 2000 sampai dengan 2004 lebih besar dibandingkan dengan ratarata produksi jenis ikan pelagis kecil lain yaitu ikan malalugis (Decapterus macarellus) 92,2\%, ikan lemuru (Sardinella sp.) 4,5\%, ikan selar (Selar crumenopthalmus) 1,9\%, ikan kembung (Rastrelliger kanagurta) 0,9\%, dan ikan tembang (Sardinella fimbriata) $0,5 \%$.

Hal tersebut menunjukkan bahwa, ke-2 ikan tersebut bukan berarti lebih menyukai ikan malalugis (Decapterus macarellus) melainkan karena ikan malalugis (Decapterus macarellus) tersebut melimpah pada habitat fishing ground. Seperti juga yang dikatakan oleh Hotta \& Ogawa, 1955; Alverson, 1963, bahwa ikan cakalang (Katsuwonus pelamis) dan ikan madidihang (Thunnus albacares) tidak menunjukkan kesukaan terhadap makanan tertentu melainkan akan memakan spesies mangsa yang ada pada habitat. Ditambahkan pula oleh Effendie (2002), bahwa faktorfaktor yang menentukan suatu spesies memakan jenis makanan antara lain ketersediaan jenis makanan tersebut di habitat. Variasi dalam volume dan frekuensi makanan ikan cakalang (Katsuwonus pelamis) ditunjukkan dengan jumlah dan ukuran spesies mangsa di lokasi penelitian. Hal tersebut, menunjukkan bahwa keberadaan ke-2 spesies tersebut tidak tergantung oleh keberadaan ikan malalugis (Decapterus macarellus). Ikan malalugis (Decapterus macarellus) sebagai makanan utama karena ikan malalugis (Decapterus macarellus) merupakan jenis ikan pelagis kecil dominan di perairan tersebut. Jika populasi ikan malalugis (Decapterus macarellus) semakin menurun, maka ke-2 spesies tersebut akan memakan jenis ikan lain yang jumlahnya melimpah di perairan tersebut sehingga keberadaan ikan cakalang (Katsuwonus pelamis) dan ikan madidihang (Thunnus albacares) tetap terjaga.

Selama analisis isi lambung ditemukan lambung yang kosong baik ikan cakalang (Katsuwonus pelamis) maupun ikan madidihang (Thunnus albacares). Dari 69 contoh ikan cakalang 
(Katsuwonus pelamis), 55,1\% (38 contoh) lambung dalam keadaan kosong dan untuk ikan madidihang (Thunnus albacares), dari 63 contoh 17,5\% (11 contoh) lambung dalam keadaan kosong, disajikan dalam Tabel 1 sebagai berikut.

Beberapa hasil penelitian telah dilakukan di beberapa lokasi dan hasil bervariasi untuk tiap-tiap lokasi. Postel (1955a; 1962) menemukan sekitar 75\% ikan cakalang (Katsuwonus pelamis) yang di pengambilan contoh di perairan Cuba, lambung kosong. Di Pasifik Barat, sekitar 56\% lambung kosong (Alverson, 1963). Nakamura (1965) menemukan 26,2 dan 27,4\% lambung kosong untuk jantan dan betina di dekat Pulau Tuamotu dan Marguesas. Raju (1964) menemukan 11,6 sampai dengan 40,5\% lambung ikan cakalang (Katsuwonus pelamis) yang tertangkap di Laut Laccadive, dalam keadaan kosong. Ikan tersebut dikatakan ditangkap dengan alat tangkap hook and line atau purse seine.

Tabel 1. Jumlah lambung ikan cakalang (Katsuwonus pelamis) dan ikan madidihang (Thunnus albacares) pada pengambilan contoh dengan persentase lambung kosong dan lambung berisi makanan

Table 1. Number of skipjack (Katsuwonus pelamis) and yellow fin tuna (Thunnus albacares) stomachs sample with percentages of empty and non empty stomachs

\begin{tabular}{lccc}
\hline \multicolumn{1}{c}{ Jenis/Species } & $\begin{array}{c}\text { Jumlah contoh/ } \\
\text { Number of sample }\end{array}$ & $\begin{array}{c}\text { \% Lambung kosong/ } \\
\text { \% Empty stomachs }\end{array}$ & $\begin{array}{c}\text { \% Lambung berisi makanan/ } \\
\text { \% Non empty stomachs }\end{array}$ \\
\hline $\begin{array}{l}\text { Cakalang/ } \\
\text { Skipjack tuna }\end{array}$ & 69 & 55,1 & 44,9 \\
$\begin{array}{l}\text { Madidihang/ } \\
\text { Yellow fin tuna }\end{array}$ & 63 & 17,5 & 82,5 \\
\hline
\end{tabular}

Selanjutnya menurut Batts (1972), dikatakan bahwa tidak ada hubungan antara metode penangkapan dengan persentase lambung yang kosong. Faktor penting yang menyebabkan lambung dalam keadaan kosong, dimungkinkan karena spesies mangsa yang telah dimakan dimuntahkan kembali. Tidak ada data yang dapat membuktikan ada ikan yang memuntahkan kembali mangsa yang telah dimakan.

Kemungkinan lain adalah karena ketika tertangkap ikan tersebut belum makan sehingga waktu tertangkap, lambung ikan dalam keadaan kosong. Perut kosong bukan berarti ikan lapar karena ikan juga mempunyai waktu makan. Berdasarkan pada penelitian di Samudera Atlantik, Grudinin (1989) mengatakan bahwa Thunnus albacares mulai makan sekitar pukul $07.00 \mathrm{am}$, terus makan perlahan-lahan dan mencapai puncak pada sekitar pukul 03.00 pm dan berhenti makan pada pukul 09.00 pm. Sedangkan di perairan Hawaii, Nakamura (1965) mengatakan bahwa ikan cakalang yang tertangkap di waktu pagi hari dan menjelang malam (sore sekali) mempunyai volume lambung lebih besar dibandingkan dengan ikan yang ditangkap pada tengah hari. Perbedaan waktu penangkapan menyebabkan perbedaan volume lambung dari ikan yang tertangkap. Seperti halnya yang dikatakan oleh Kaymaram et al. (2003), bahwa ada lambung kosong dalam jumlah yang cukup tinggi karena waktu penangkapan setelah matahari terbenam, artinya bukan waktu makan bagi ikan tersebut.

\section{KESIMPULAN}

1. Komposisi jenis makanan ikan cakalang (Katsuwomus pelamis) adalah ikan malalugis (Decapterus macarellus) dengan rata-rata ukuran panjang 12,4 cm (57\%), ikan sardin (Clupeidae) dengan rata-rata ukuran panjang $12,2 \mathrm{~cm}(9 \%)$, ikan kembung (Rastrelligersp.) dengan rata-rata ukuran panjang $23 \mathrm{~cm}(4 \%)$, kepiting (Portunidae) $0,09 \%$ dan didominasi oleh ikan malalugis (Decapterus macarellus).

2. Komposisi jenis makanan ikan madidihang (Thunnus albacares) adalah ikan malalugis (Decapterus macarellus) dengan rata-rata ukuran panjang 24,8 (54\%), ikan suro atau sunglir (Elagatis bipinnulatus) dengan rata-rata ukuran panjang $32 \mathrm{~cm}(5 \%)$, ikan deho (Auxis thazard) dengan rata-rata ukuran panjang $21,5 \mathrm{~cm}(1 \%)$, sedangkan cumi (Lolliginidae), udang (Penaeidae), ikan buntal (Ostraciidae) dengan rata-rata ukuran panjang $4,5 \mathrm{~cm}$ dengan persentase sangat kecil $(0,001$ sampai dengan $0,02 \%)$ dan didominasi oleh ikan malalugis (Decapterus macarellus).

3. Ikan cakalang (Katsuwomus pelamis) dan ikan madidihang (Thunnus albacares) memiliki kesamaan terhadap 1 jenis makanan utama yaitu ikan malalugis (Decapterus macarellus) dengan ukuran panjang yang berbeda. 